\title{
A Comparative Study of Helminths Parasites in Catfishes
}

\author{
Anita Singh", Suman Mishra ${ }^{2}$ \\ Department of Applied Animal Sciences, BabasahebBhimraoAmbedkar University, VidyaVihar, Raebareli Road, Lucknow-226025 (U.P.)
}

\begin{abstract}
Fish is one of the best sources of proteins for human beings, so it is important that they should be healthy and free from infections. Fishes are often found infected with a parasites; Trematoda, Nematoda, Cestoda, and Acanthocephala; causing infectious diseases. Among different fish diseases, Gyrodactylussalaris, Ichthyophthiriusmultifiliis, flukes, are most prevalent in fish population that causes great mortality. In case of severe infection by parasites, fish development is hindered causing emaciation of affected fish. The major parasitic groups found in freshwater fishes are trematodes, cestodes, acanthocephalans and nematodes. In the present study, the prevalence of helminth parasites has been observed two freshwater fishesChanna punctatus (Bloch) and Wallago attu. Live fresh specimens of Channa punctatus (Bloch) and in Wallago attu of all sizes, weight and sex were collected from river gomti, Lucknow and transported from the sampling area to the laboratory in aerated container in dechlorinated water. A total of 180 fishes were examined for the presence of helminth parasites in which a total no. of parasites found in Channa punctatus was 100 and in Wallago attu was 80. In case of Channa punctatus (Bloch) $31 \%$ of total collected fishes and in Wallago attu $13.7 \%$ of total collected fishes were found to be infected with helminth parasites.
\end{abstract}

Keywords: Survey, Helminth parasites, Freshwater fishes, Channa punctatus, Wallago attu.

\section{Introduction}

Fishes are good source of protein that can bedigested easily. These are important components of ecosystem from ecological, medicinal, nutritional and economical point of view. A majority of freshwater fishes carry heavy infection of parasites (Trematodes, Nematodes, Cestodes and Acanthocephalans) which cause deterioration in the food value of fish and even result in their mortality. Besides these, there are a number of helminth parasites which are transmitted to human beings only through fish (Gupta, 1959). These parasites use the fish for their shelter and food, and destruct every organ resulting in pathogenic effects (Dogiel, 1958). Parasites interfere with the nutrition; metabolism and secretary function of alimentary canal, damage nervous system (Markov, 1961), and even upset the normal reproduction of the host (Faust, 1949). Vermaet al. (2013) studied the parasitic infection index in edible fish ie.,Catlacatla, Channa punctatus and Cirrhinusmrigala, in extensive survey made at different places in river Yamuna at Agra in the rainy seasons during year 2009 and 2010. Recently, Qadriet al. (2013) have made some attempts to explore the fauna of helminth parasites in three commercially important catfishes, Wallago attu, $O$. pabda and A. seenghala in regions of Bhopal.Wallago attuand Channa punctatus both, are common food catfishes. The Channa punctatus is very economical with high nutritional value and market demand because of its relatively low cost and high availability; and Wallago attu are the easily available in the fish market. Due to their feeding habit, fishes can act as an intermediate or a final host for many helminth parasites. To obtain healthy and quality meat fish, it is essential that the fish should be free from all types of infections like viral, bacterial, and parasitic. The major parasitic groups found in freshwater fishes are trematodes, cestodes, acanthocephalans and nematodes. Since human preferring white meat source is utilizing these fishes, so it is important to study the prevalence of parasites in these fishes.The present study is aimed to investigate the burden and effect of helminth parasites in freshwater catfishes Wallago attu and Channa punctatus (Bloch) obtained from River Gomti in Lucknow, U.P.

\section{Materials and MMethods}

1) Study area: GomtiRiver, Lucknow.

2) Study periods: July, 2012 -December, 2012.

3) Study organism: Freshwater fishes (Channa punctatus and Wallago attu).

4) Collection of host fishes: Live fresh specimens of Channa punctatusand Wallagoattuof all sizes, weight and sex werecollected from River Gomti in Lucknow. The specimens were brought in the laboratory alive in a small container with water and maintained in glass aquaria.

5) Methodology:

a) Total and Standard Length and Weight
The total and standard length of the fish were measured in centimeter $(\mathrm{cm})$ using a measuring board. Fish were weighed to the nearest gram (g) using weighing balance (Paperna, 1996).

b) Examination for Helminth Parasites:

In the laboratory all samples were examined and processed as per standard protocol. External examination of each fish for the helminths ectoparasites was conducted using hand lens. Each gill was examined individually for the presence of parasite. Fishes were opened up dorso-ventrally and all the internal organs were examined separately. The entire digestive system was removed and placed in a petri dish with saline for further examination.

c) Processing of parasites for identification:

The Trematodes were fixed in hot $10 \%$ formalin, cestodesand acanthocephala were fixed in AFA solution following staining by borax carmine. After staining, 


\section{International Journal of Science and Research (IJSR) \\ ISSN (Online): 2319-7064 \\ Index Copernicus Value (2013): 6.14 | Impact Factor (2015): 6.391}

parasites were washed with distilled water, dehydrated in ascending grades of alcohol, cleared in xylene and mounted in D.P.X. Helminth parasites were identified up to class level on the basis of available taxonomical characters as described by Yamaguti, 1958; 1961; 1963.

\section{d) Formula and statistical Analysis}

Prevalence, Abundance and Mean density, Index of infection were determined by following the formula proposed by Margolis et al.(1982).

Prevalence $=\frac{\text { Total no. of infected fishes }}{\text { Total no. of fishes host examined }} \times 100$

Abundance $=\frac{\text { Total no. of parasites recovered }}{\text { Total no. of fish hosts examined }}$

Mean density $=\frac{\text { Total no.of parasites recovered }}{\text { Total no.of infected host examined }}$

Index of infection $=\underline{\text { No.of host infected } \times \text { No.of parasites collected }}$ Total host examined

Statistical analysis (Chi-squared test) was done by SPSS 16.0 version software.

\section{Results and Discussion}

The results obtained in the present study are depicted in table 1 to 7 and figure 1 to 7 . A total no. of 180 specimens of the two species of freshwater catfishesChanna punctatusand Wallago attuwere examined, for the presence of helminths parasites. Out of a total of 180 fishes, 31(31\%)Channa punctatus and 11 $(13.75 \%)$ Wallago attu were found to be infected with different helminth parasites. (Figure 1)

Table 1: Species wise prevalence of helminth parasites

\begin{tabular}{|c|c|c|c|c|}
\hline Fish species & $\begin{array}{c}\text { No. of fish } \\
\text { examined }\end{array}$ & $\begin{array}{c}\text { No. of fish } \\
\text { infected }\end{array}$ & $\begin{array}{c}\text { No. of } \\
\text { parasites }\end{array}$ & Prevalence \\
\hline Channa punctatus & 100 & 31 & 60 & 31 \\
\hline Wallago attu & 80 & 11 & 18 & 13.75 \\
\hline Total & 180 & 42 & 78 & \\
\hline
\end{tabular}

\section{1: Prevalence of parasites in Catfishes, Wallago attu and \\ Channa punctatus}

To observe parasitic infection in two edible fish species viz., C. punctatusand Wallago attu were collected from River Gomti, Lucknow and examined critically. Out of 100 specimens of $C$. punctatus were examined, 31 were found infected with helminths parasites. Whereas 11 out of 80 specimens of Wallago attu werefound to be infected. The maximum prevalence (31\%) showed by C. punctatuswhile $(13.75 \%)$ shown by Wallago attu.(Table 1, Fig. 1). Recently,Vermaet al., 2013, also recorded prevalence of helminth parasites in same fish $C$. punctatusthey were found to be infected with three species of helminth parasites, the parasites were associated with gill, stomach and intestine of fishes respectively and Qadri et al2013, also reported prevalence of helminth parasites and compare with the other fish.

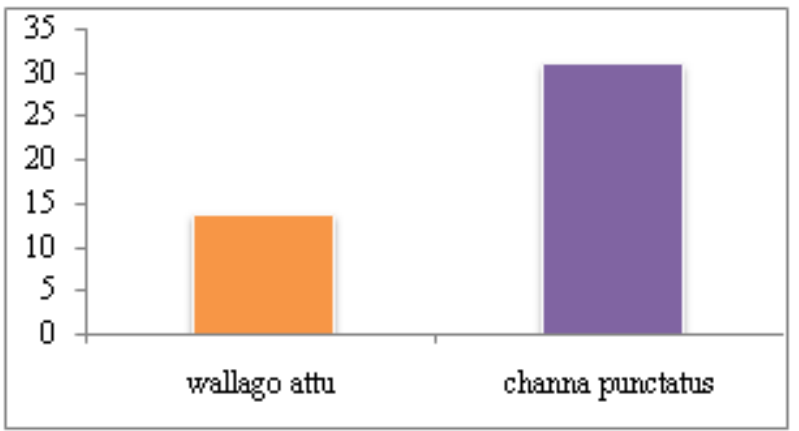

Figure 1: Prevalence of parasite in two catfishes, Wallago attu and Channa punctatus

Relation between host (Channa punctatus) length and parasitic infection- It was observed that an increase in the size of fish host was accompanied with an increase inparasitic infection. The larger fishes $(11-14.9 \mathrm{~cm})$ were more heavily infected than the smaller fishes $(7-10.9 \mathrm{~cm})$. Figs.2.shows the increase in the Index and mean intensity with the increase in size (length) of the host. Kaur et al. observed that the similarly, the large fishes $(<15 \mathrm{~cm})$ were more heavily infected than the smaller fishes $(>10 \mathrm{~cm})$. Arme(2002) further explained the reason for gradual increase in intensity of infection with increase in size (length) and according to the author it may be due to the accumulation of plerocercoids in fish as they grow and it is accepted that the plerocercoids may survive in fish for several years.

Chi square test revealed that there was significant difference in prevalence of helminthes parasites among the three length classes of the examined host.

Table 2: Relation between standard length and different indices of parasitic infection in Channa punctatus.

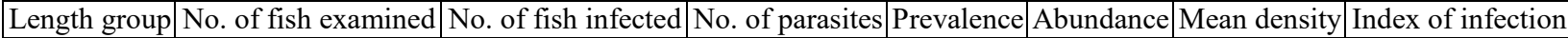

\begin{tabular}{|c|c|c|c|c|c|c|c|}
\hline $7-10.9$ & 29 & 8 & 10 & 27.5 & 0.34 & 1.25 & 2.7 \\
\hline $11-14.9$ & 55 & 18 & 39 & 32.7 & 0.70 & 2.1 & 12.7 \\
\hline $15-18.9$ & 16 & 5 & 11 & 31.2 & 0.68 & 2.2 & 3.4 \\
\hline Total & 100 & 31 & 60 & 91.4 & 1.72 & 5.55 & 18.8 \\
\hline
\end{tabular}

Volume 5 Issue 7, July 2016 www.ijsr.net 


\section{International Journal of Science and Research (IJSR) \\ ISSN (Online): 2319-7064 \\ Index Copernicus Value (2013): 6.14 | Impact Factor (2015): 6.391}

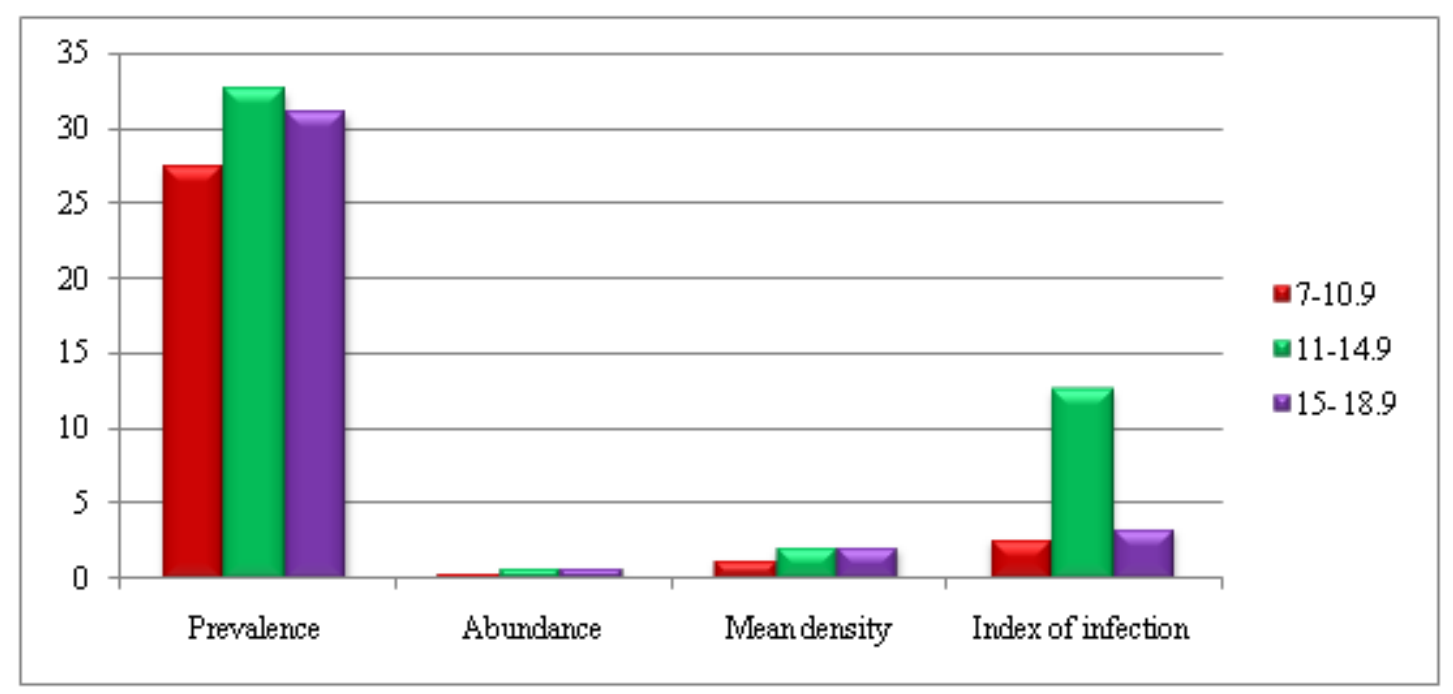

Figure 2: Relation between standard length and different indices of parasitic infection in Channa punctatus.

Relation of host Body weight and parasitic infection: - In relation to studies on host body weight and parasitic infection, it was observed that the percentage of infection increased with increasing weight. The bigger fishes ( 71 to 90 gm) were more heavily infected than the smaller fishes (20 to $50 \mathrm{gm}$ ) (Table 3, Figure 3). Parallel observations were stated by Ayanda (2009) and Olurin and Samorin, (2006), According to these workers, the heavier the fish, the greaterthe vulnerability to parasitic infection. This observation could berecognized to the fact that larger fish provides larger surface area for the infection to multiply in numbers than the smaller ones. Another plausible reason could be that the relation may be the result of changes in diet from phytoplankton and zooplankton to insects, larvae, snails, worms and crustaceans forfood as smaller fishes grow into larger ones (Obanoet al., 2010b). Chi square test revealed that there were significant differences in prevalence of helminthes among the three weight classes of the examined host.

Table 3: Relation between body weight and different indices of parasitic infection in Channa punctatus

\begin{tabular}{|c|c|c|c|c|c|c|c|}
\hline Body weight & No. of fish examined & No. of fish infected & No. of parasites & Prevalence & Abundance & Mean density & Index of infection \\
\hline $20-50$ & 60 & 21 & 42 & 35 & 0.7 & 2 & 14.7 \\
\hline $51-70$ & 35 & 8 & 15 & 22.8 & 0.42 & 1.8 & 3.4 \\
\hline $71-90$ & 5 & 2 & 3 & 40 & 0.6 & 1.5 & 1.2 \\
\hline Total & 100 & 31 & 60 & 97.8 & 1.72 & 5.3 & 19.3 \\
\hline
\end{tabular}

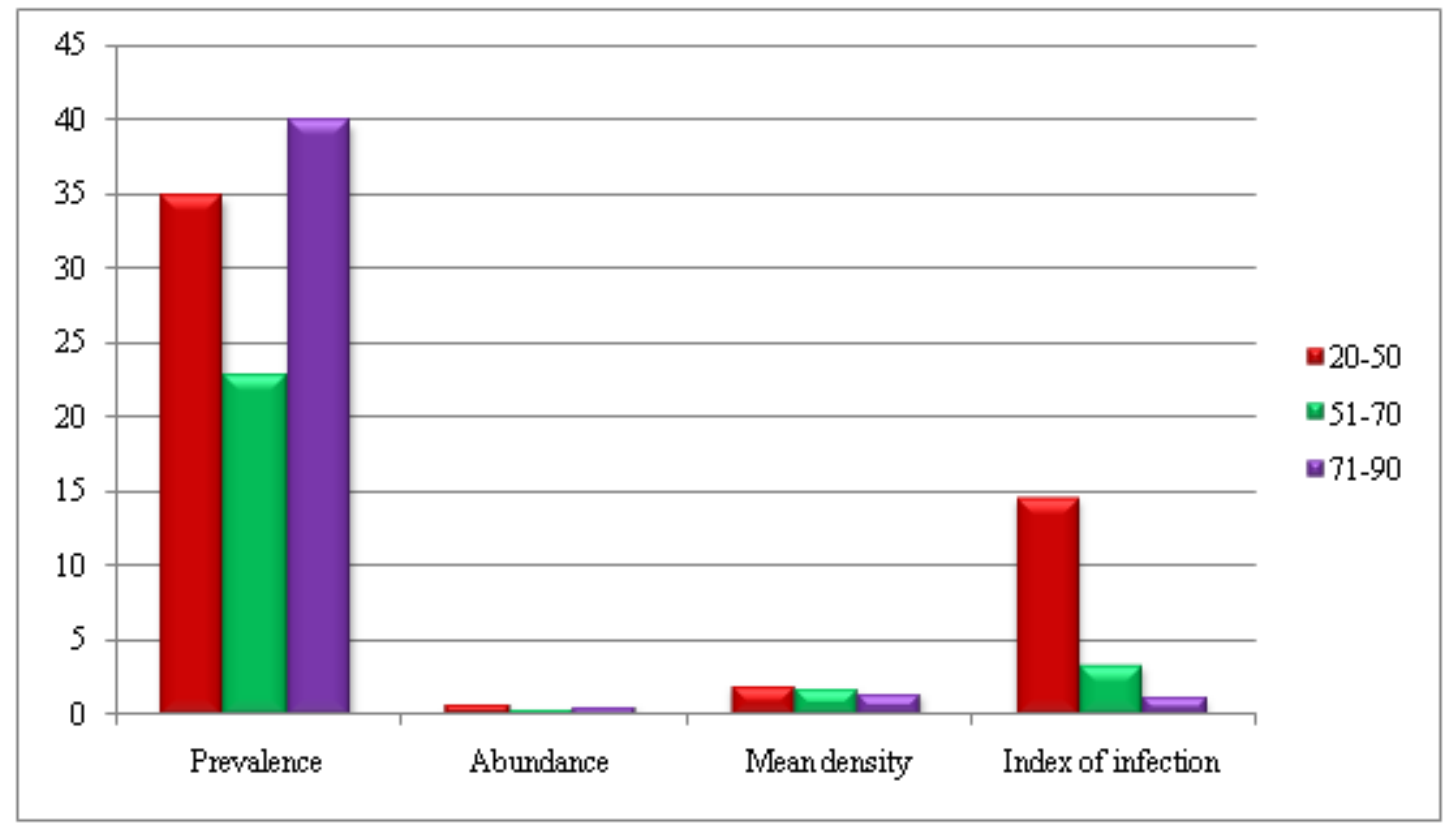

Figure 3: Relation between body weight and different indices of parasitic infection in Channa punctatus

Volume 5 Issue 7, July 2016 www.ijsr.net 


\section{International Journal of Science and Research (IJSR) \\ ISSN (Online): 2319-7064 \\ Index Copernicus Value (2013): 6.14 | Impact Factor (2015): 6.391}

Relation between host Sex and Parasitic infection-The total fishes were (Channa punctatus) examined, 18 out of 55 females $(32.72 \%)$ were found infected with parasites as comparison to 13 out of $45(28.88 \%)$ males (Table 4, Figs. 4). Present study was revealed that female host was observed to be more infected than males. Similar reports were also observed by Thomas (1964) Chandra (1985)Khanum and Parveen (1997)and Rahman and Saidin (2011). These workers concluded that this relation may be due to lower physiological resistance of female fishes as compared to the males. According to Dobson (1961) female are more susceptible to parasite infection during breeding season.

Chi square test revealed that there was non- significant the differences in prevalence of the infection in males and female of the examined host fishes.

Table 4: Relation between body sex and different indices of parasitic infection in Channa punctatus

\begin{tabular}{|c|c|c|c|c|c|c|c|}
\hline Sex & No. of fish examined & No. of infected fish & No. of parasites & Prevalence & Abundance & Mean density & Index of infection \\
\hline Male & 45 & 13 & 21 & 28.88 & 0.46 & 1.61 & 6.06 \\
\hline Female & 55 & 18 & 29 & 32.72 & 0.52 & 1.61 & 9.49 \\
\hline Total & 100 & 31 & 50 & 61.6 & 0.98 & 3.22 & 15.55 \\
\hline
\end{tabular}

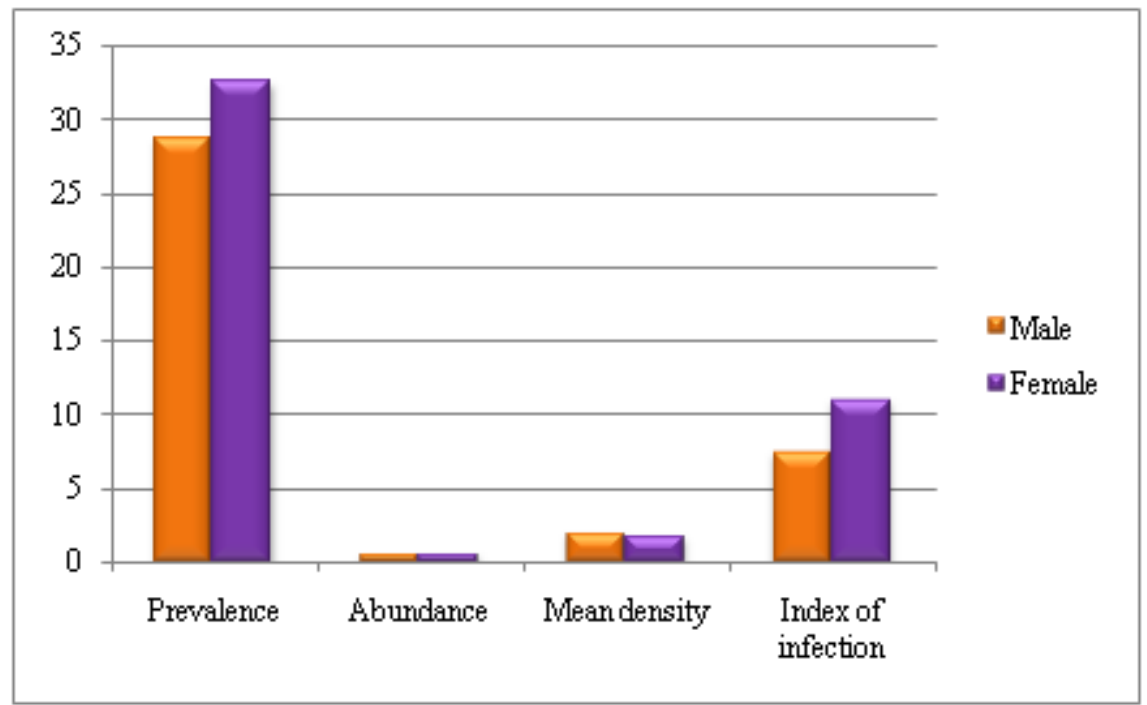

Figure 4: Relation between body sex and different indices of parasitic infection in Channa punctatus

Relation betweenhost (Wallago attu) size (length) and parasitic infection:In this study, we observedthe relationship between length of the fishand the percentage of infected fishes. It is also investigated which length of Wallago attumore infectedwith parasites than the others. The size of normal and infected fishes was grouped in length classes (17 to 21.9, 22 to 26.9 and 27 to 31.9).(Table 5,Fig. 5)showed that the percentage of infection of both the normal and infected fishes in each length group. Itcan be concluded from the given data that the smallest fishes in length group from $17 \mathrm{~cm}$ to $21.9 \mathrm{~cm})$ were relatively less infected than the other length groups and the percentage of infectionincreases with increasing fish length. It was concluded that, larger fishes were heavily parasitized thansmaller ones. Bashirullah(1973)and Dogiel (1961)also reported that the degree of parasitism was obviously related to the food habit and age ofthe fishes.

Chi square test revealed that there was no significant difference in prevalence of helminths among the three length classes of the examined host.

Table 5: Relation between standard length and different indices of parasitic infection in Wallago attu.

\begin{tabular}{|c|c|c|c|c|c|c|c|}
\hline Length group & No. of fish examined & No. of fish infected & No. of parasites & Prevalence & Abundance & Mean density & Index of infection \\
\hline $17-21.9$ & 24 & 2 & 5 & 8.3 & 0.20 & 2.5 & .41 \\
\hline $22-26.9$ & 40 & 7 & 9 & 17.5 & 0.22 & 1.2 & 1.5 \\
\hline $27-31.9$ & 16 & 2 & 4 & 12.5 & 0.25 & 2 & 0.5 \\
\hline Total & 80 & 11 & 18 & 38.3 & 0.67 & 5.7 & 2.41 \\
\hline
\end{tabular}

Volume 5 Issue 7, July 2016 www.ijsr.net 


\section{International Journal of Science and Research (IJSR) \\ ISSN (Online): 2319-7064 \\ Index Copernicus Value (2013): 6.14 | Impact Factor (2015): 6.391}

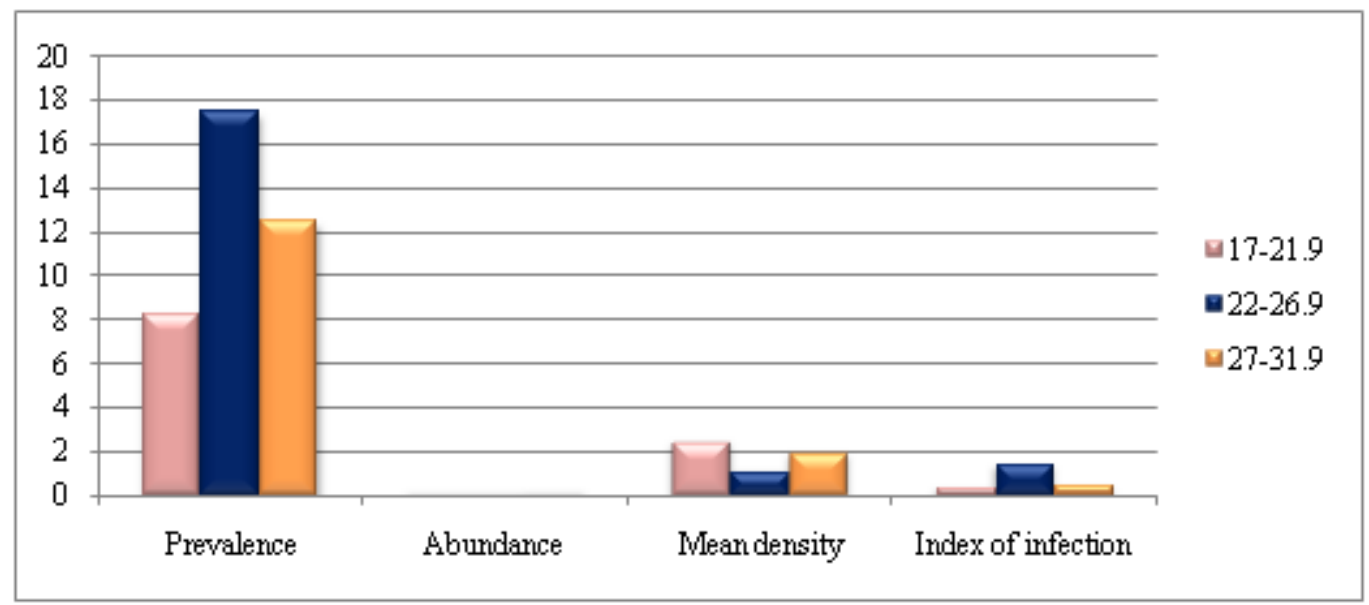

Figure 5: Relation between standard length and different indices of parasitic infection in Wallago attu.

Relation between host (Wallago attu) Body weight and parasites-We observed that the bigger fishes (151 to $210 \mathrm{gm})$ were more heavily infected than the smaller fishes (30 to 90gm). Table1 and Figure 6: shows prevalence, abundance, mean density of parasitic infection and index of infection according to body weight of Wallago attu. Highest Prevalence $(30 \%)$ was observed in the body weight range of 151 to -
$210 \mathrm{gm}$ with Abundance of 0.7, Density of infection of 2.3 and Index of infection of 2.1. There was an observed increase in Incidence of infection with increase in body weight.Chi square test revealed that there were significant $(\mathrm{P}<0.05)$ differences in prevalence of helminthes among the three weight classes of the examined host.

Table 6: Relation between body weight and different indices of parasitic infection in Wallago attu .

\begin{tabular}{|c|c|c|c|c|c|c|c|}
\hline Body weight & No. of fish examined & No. of fish infected & No. of parasites & Prevalence & Abundance & Mean density & Index of infection \\
\hline $30-90$ & 55 & 4 & 6 & 7.2 & 0.1 & 1.5 & 0.43 \\
\hline $101-160$ & 15 & 4 & 5 & 26.6 & 0.3 & 1.2 & 1.3 \\
\hline $161-220$ & 10 & 3 & 7 & 30 & 0.7 & 2.3 & 2.1 \\
\hline Total & 80 & 11 & 18 & 63.8 & 1.1 & 5 & 3.83 \\
\hline
\end{tabular}

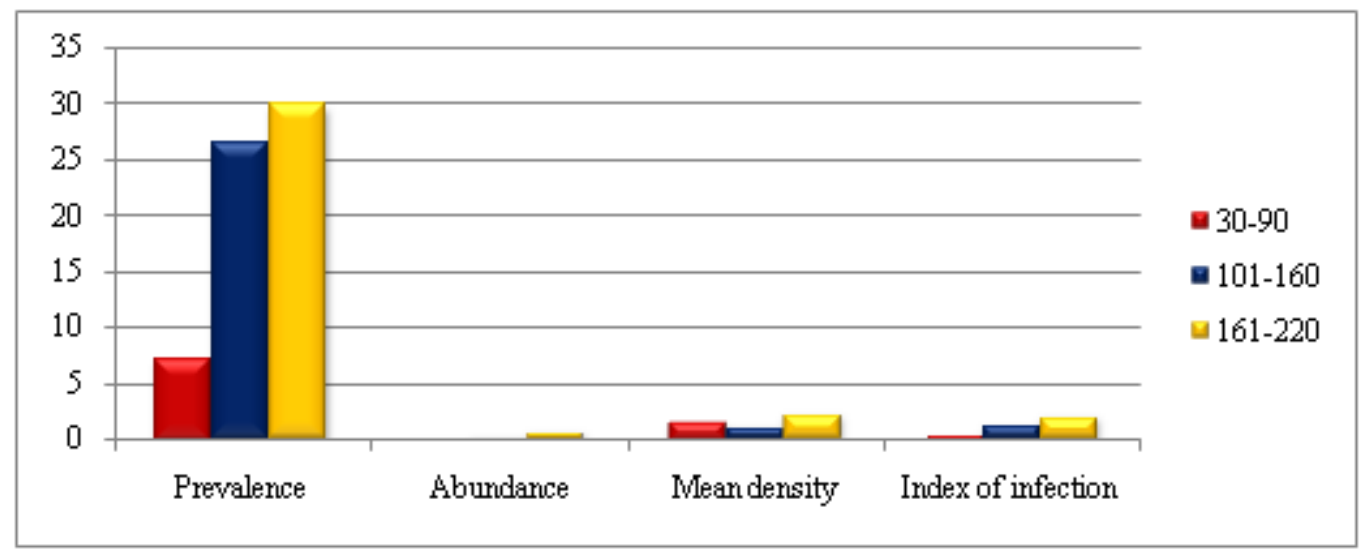

Figure 6: Relation between body weight and different indices of parasitic infection in Wallago attu

Relation to Sex of host and parasitic infection:-Out of the total fishes examined, 5 were infected out of 35 female and 6 were infected out of 45 males. The Prevalence of the parasitic infection (\%) in the female and male was 14.2 and 13.3 respectively during this period. The abundance, density and index of infection in female was $0.2,1.4$ and 1 and in male .24, 1.8 and1.46 respectively (Table 7, Fig, 7).Chi square test revealed that there was no significant difference in prevalence of the infected males and female of the examined host fishes.

Table 8: Relation between sex and different indices of parasitic infection in Wallago attu

\begin{tabular}{|c|c|c|c|c|c|c|c|}
\hline Sex & No. of fish examined & No. of infected fish & No. of parasites & Prevalence & Abundance & Mean density & Index of infection \\
\hline Male & 45 & 6 & 11 & 13.3 & .24 & 1.8 & 1.46 \\
\hline Female & 35 & 5 & 7 & 14.2 & 0.2 & 1.4 & 1 \\
\hline Total & 80 & 11 & 18 & 27.5 & 0.44 & 3.2 & 2.46 \\
\hline
\end{tabular}

Volume 5 Issue 7, July 2016 www.ijsr.net 


\section{International Journal of Science and Research (IJSR)}

ISSN (Online): 2319-7064

Index Copernicus Value (2013): 6.14 | Impact Factor (2015): 6.391

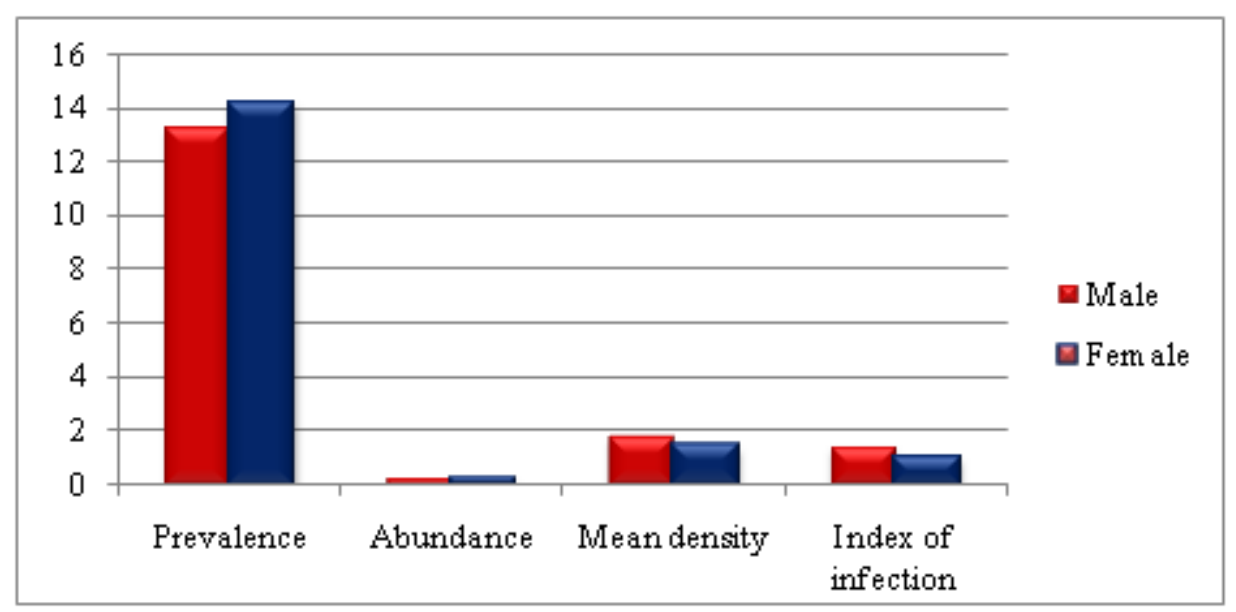

Figure 7: Relation between sex and different indices of parasitic infection in Wallago attu

\section{Conclusion}

The present study has shown that two catfishes from the River gomti harbor a wide range of parasites especiallythe helminth parasites. The study has established that the Channa punctatus fish is one of the most heavily infected fish species as compare to Wallago attu. This study thus highlights on the parasitic infection according to the length, weight andsex. We concluded thatthe freshwater fishes harbour a wide range of helminth parasites especially trematodes and acanthocephala. Out of a total of 180 fish examined 42 were found to be infected with helminth parasites. The overall prevalence of parasites was found to be 23.3. The maximum infection of helminth parasites was found in Channa punctatus in comparison Wallago attu.The maximum infection of helminth parasites was found in the fishes weighing 71-90g and in the fish length ranging from $11-14.9 \mathrm{~cm}$ in case of channa punctatus. The maximum infection of helminth parasites was found in the fishes weighing $161-220 \mathrm{~g}$ and in the fish length ranging from $22-26.9 \mathrm{~cm}$ in case of Wallago attu.

\section{Future Scope}

Fishes arean important source of protein that consumed by human being. Butmajority of freshwater fishes carry heavy infection of parasites which cause deterioration in the food value of fish and even result in their mortality. The fishery industry also plays an important role in the Indianeconomy as they provide employment opportunities. However, due to the occurrence of these parasites, the physiological activities of the infected fishes are hindered and their growth is retarded. Beside this, there is always the possibility of their transfer to the human beings by consumption of infected fishes. Therefore, it is important to carry out the prevalence of helminth parasites in fishes.

\section{References}

[1] Ayanda,O.I. (2009): Comparative parasitic helminth infection between cultured and wild species of Clariasgariepinusin IIorin, North Central Nigeria.
ScientificResearch and Essay, 4(1): 18-21.Edinburg and London. Pp.117-139.

[2] Bahirullah, A.K.M. (1973): A brief survey of helminth fauna of certain marine and freshwater fishes of Bangladesh J. Zool. 1 (I): 63-81.

[3] Chandra, K.J. (1985): Records of some Trypanorhychpleurocercoids in teleosts of Andhra coast. Indian J. Parasitol.1985, 9: 35 - 137.

[4] Dobson, C. (1961) certain aspects of the host parasites relation of nematode Spirudaedubius(Buylis), I, resistance of male and female mice to experiment infection. Parasitol., 51:173-179.

[5] Dogiel, V.A. (1961):Ecology of parasites of fresh water fishes, Parasitology of fishes, Transl. by Kabata. Z. (1961) Oliver and Boyd, Edinburgh, 1958, pp. 1-47

[6] Faust, E.C. (1949): Human Helminthology. Lea and Febriger, Philadelphia.

[7] Gupta, S.P. (1959): Nematode parasites of vertebrates of East Pakistan. III. Camallanidae from Fishes, Amphibia and Reptiles. Can. J. Zool., 87:771-779.

[8] Kaur, Pinky, Shrivastav, Rekha, Qureshi, T.A., Manohar, Susan, Saroch, J.D. and Sharma, Shivani. (2012): Host Parasite Relationship: Sengasp. (Dollfus, 1934) In Association with Naturally Infected Freshwater Host Fish Channa punctatus (Bl.).J.Chem. Bio. Phy. Sci. Sec.D, Vol. 2, No. 4, 2175-2181.

[9] Khanum, H. and Parveen, S. (1997): Organal distribution and seasonal prevalence of endoparasites in MacrognathusaculeatusSmith and MacrognathusarmatusDay. Bangladesh J. Zool. 1997, 25(1): $15-21$.

[10] Khanum, H., Begum, N. and Begum, A. (2008): Infestation of helminth parasites in the Pannamicrdon(Bleeker, 1849). Dhaka Univ. J. Biol. Sci., 17(1): $51-57$.

[11] Margolis, L., Esch, G. W., Holmes, J. C. and Schod, G. A. (1982): The use of ecological terms in parasitology. Report of an ad-hoc Committee of the American Society of Parasitologists.J. Parasit. 68, 131-133.

[12] Markov, G.S. (1961): Physiology of fish parasites. In: parasitology of fishes (V.A. Dogiel, G.K.of Bangladesh. Bangladesh. J. Zool. 1973, 1: 63-81

Volume 5 Issue 7, July 2016 


\section{International Journal of Science and Research (IJSR) \\ ISSN (Online): 2319-7064 \\ Index Copernicus Value (2013): 6.14 | Impact Factor (2015): 6.391}

[13] Mofasshalin, M.S., Bashar, M.A., Alam, M.M., Alam, G.M., Moumita, D., Mazlan, A.G. and Simon, K.D. (2012). Parasites of Three Indian Minor Carps of Rajshahi, Bangladesh.Asian Journal of Animal and Veterinary Advances, 7: 613-620.

[14] Olurin, K.B. and Samorin, C.A. (2006): Intestinal helminthes of the fishes of Owa stream, South-west Nigeria. Res. J.Fisheries and Hydrobiology, 1(1):6-9.

[15] Paperna I. (1996): Parasites, infections and diseases of fishes in Africa - an update, CIFA Technical Paper No. 31, Rome, FAO, 220p.Petrushevesky \& Yu, I. polyansky eds.) English Translation by Z. Kobata., Oliver and Boyed,

[16] Rahman, W.A. and Saidin, H. (2011): Relationship between sex and parasite intensity in fourfresh water fish species from TasikMerah, Perak, Peninsular Malaysia.

[17] Thomas, J.D. (1964): A comparison between the helminth burdens of male and female brown trout, SalmotruttaL., from a natural population in the river Trify. West Wales. Parasitology, 4: $263-272$.

[18] Verma, N. and Capoor, A. (2013). Population dynamics of helminth parasites in some edible fishes of river Yamuna, WJASR, Volume 3, Issue 2, Pages 54-60, ISSN 22549-4197.

[19] Yadav S., Chandra S. and Saxena A.M. (2010) an ecological study on digenetic trematode parasite of Channa punctatus of Lucknow, Uttar Pradesh, Lucknow journal of science: vol. 7, no.2, pp.1-8.

[20] Yamaguti S.(1958) Systemahelminthum vol. 1 The digenetic trematodes of vertebrates. Int. Sci. pub.NewYork 1575.

[21] Yamaguti S.(1961) Systemahelminthum vol. 2 The Cestode of vertebrates. Int. Sci. pub. INC, NewYork and London, 1-860

[22] Yamaguti S.(1961) Systemahelminthum vol. 3part $1^{\text {st }}$ and $2^{\text {nd }}$ The Nematode of vertebrates. Int. Sci. pub.INC, NewYork and London.

[23] Yamaguti S.(1963) Systemahelminthum vol. 5: Acanthocephala. Int. Sci. pub. INC, NewYork and London, 1-423.

\section{Author Profile}

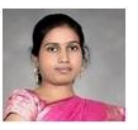

Anita Singh is pursuing $\mathrm{PhD}$ from Department of Applied Animal Sciences at Babasaheb Bhimrao Ambedkar University (A central University) Lucknow under the supervision of Dr. Suman Mishra. She has participated and presented her work in several International and National Conferences. Her area of Research Interest includes Fishries and Parasitology

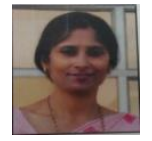

Dr. Suman Mishra is working as Assistant Professor in Department of Applied Animal Sciences at Babasaheb Bhimrao Ambedkar University (A central University) Lucknow. She has a decade long and bright teaching and research experience. She is having one International and one national patent to her credit. She has published several Research paper in reputed International and national journals and 6 Books. Dr. Mishra has been honoured with several prestigious awards. She is also member of editorial team of the Indian journal of Helminthology. She has participated the InspiredTeacher In - Residence Programme of the President of India at Rashtrapatibhawan in New Delhi. Her area of research interest includes Parasitology

Volume 5 Issue 7, July 2016 www.ijsr.net 